Article

\title{
Evaluation of Hyperspectral Reflectance Parameters to Assess the Leaf Water Content in Soybean
}

\author{
Marek Kovar ${ }^{1, *}$, Marian Brestic ${ }^{1}$,, Oksana Sytar $^{1}$, Viliam Barek ${ }^{2}$, Pavol Hauptvogel ${ }^{3}$ \\ and Marek Zivcak ${ }^{1, *(D)}$
}

1 Department of Plant Physiology, Faculty of Agrobiology and Food Resources, Slovak University of Agriculture, Tr. A. Hlinku 2, 94976 Nitra, Slovakia; marian.brestic@uniag.sk (M.B.); oksana.sytar@gmail.com (O.S.)

2 Department of Water Resources and Environmental Engineering, Faculty of Horticulture and Landscape Engineering, Slovak University of Agriculture, Tr. A. Hlinku 2, 94976 Nitra, Slovakia; viliam.barek@uniag.sk

3 National Agricultural and Food Centre, Research Institute of Plant Production, Bratislavska cesta 122, 92168 Piešt'any, Slovakia; hauptvogel@vurv.sk

* Correspondence: marek.kovar@uniag.sk (M.K.); marek.zivcak@uniag.sk (M.Z.); Tel.: +421-37-6414-440 (M.K.); +421-37-6414-821 (M.Z.)

Received: 21 January 2019; Accepted: 25 February 2019; Published: 1 March 2019

\begin{abstract}
Nondestructive assessment of water content and water stress in plants is an important component in the rational use of crop irrigation management in precision agriculture. Spectral measurements of light reflectance in the UV/VIS/NIR region (350-1075 $\mathrm{nm}$ ) from individual leaves were acquired under a rapid dehydration protocol for validation of the remote sensing water content assessment in soybean plants. Four gravimetrical approaches of leaf water content assessment were used: relative water content (RWC), foliar water content as percent of total fresh mass (FWC ${ }^{t}$ ), foliar water content as percent of dry mass (FWC ${ }^{\mathrm{d}}$ ), and equivalent water thickness (EWT). Leaf desiccation resulted in changes in optical properties with increasing relative reflectance at wavelengths between 580 and $700 \mathrm{~nm}$. The highest positive correlations were observed for the relations between the photochemical reflectance index (PRI) and EWT $\left(r_{P}=0.860\right)$. Data analysis revealed that the specific water absorption band at $970 \mathrm{~nm}$ showed relatively weaker sensitivity to water content parameters. The prediction of leaf water content parameters from PRI measurements was better with RMSEs of $12.4 \%\left(r_{P}=0.786\right), 9.1 \%\left(r_{P}=0.736\right)$, and $0.002\left(r_{P}=0.860\right)$ for RWC, FWC $C^{t}$, and EWT $(p<0.001)$, respectively. The results may contribute to more efficient crop water management and confirmed that EWT has a statistically closer relationship with reflectance indices than other monitored water parameters.
\end{abstract}

Keywords: water; dehydration; hyperspectral reflectance; vegetation indices; remote sensing; soybean

\section{Introduction}

Water is one of the most important components of living organisms. Among abiotic stresses, the reduced availability of soil water for plants is a key environmental factor that decreases the production of many crops [1-3], including soybean [4,5]. Water stress leads to a reduction in and subsequent loss of cell turgor, resulting in a decline in plant organ expansion and growth [6]. Moreover, closure of stomata under water stress restricts the transpiration and cooling efficiency of the plant surface and limits the diffusion of carbon dioxide into the leaf and thus photosynthesis $[7,8]$.

In general, the agronomic indicator of plant water status (and implicitly the level of water stress) is the water content. In the methodology of plant physiology, approaches to determining the relative water content or water potential are frequently used $[9,10]$. These methods are based on gravimetric 
and psychrometric techniques, but both are time-consuming and labor-intensive, with low sample throughput in agronomic practice $[9,11]$.

Effective management of plant water content in field conditions depends on accurate application of irrigation. To meet the needs of precision agriculture, modern approaches in the management of agronomic interventions (including crop watering) require presymptomatic and nondestructive monitoring of plant health. Measurements of plant reflectance in visible and near infrared (VIS/NIR) and short-wave infrared (SWIR) spectral regions can be used in diagnosing plant physiological status, such as photosynthetic pigment and nitrogen contents, plant biomass, and crop structure. Thus, they may provide reliable information about plant fitness [11-16].

Hyperspectral reflectance measurements have been widely employed to assess the water content in plants [17-19]. The water absorption properties used in plant reflectance spectroscopy are the result of the vibration processes of $\mathrm{O}-\mathrm{H}$ bonds of the water molecule at $975 \mathrm{~nm}, 1175 \mathrm{~nm}, 1450 \mathrm{~nm}$, and 1950 $\mathrm{nm}$ [20]. Ripple [21] identified a high correlation between leaf water potential and leaf reflectance. Spectral reflectance measurements at different levels (leaf, plant, and canopy) have led to the development of numerous indices for estimating plant water content and water stress $[11,19,22,23]$. Peñuelas and coworkers [12] studying the reflectance of many plants under water dehydration conditions proposed the water index (WI) to monitor the relative water content in plants. In the later period, other water indices, such as the water band index (WBI), moisture stress index (MSI), normalized difference water index (NDWI), and simple ratio water index (SRWI), were successfully introduced into the field characterization of water content in vegetation $[11,23,24]$. However, the reliability of the water content estimates derived from spectral reflectance records strongly depends on the plant species tested [22].

Although the water indices based on the measurements in near infrared spectra beyond $950 \mathrm{~nm}$ were shown to be quite useful, the cost of equipment enabling reliable records in these spectral bands (usually denoted as SWIR analyzers) makes it inaccessible for many potential users. On the other hand, there is much better access to devices measuring reflectance in the visible spectra (VNIR hyperspectral and multispectral analyzers), as these devices are less expensive and they enable more versatile applications, providing numerous specific reflectance parameters. Moreover, recent progress in sensors for hyperspectral radiospectroscopy and imaging technology allows satisfactory evaluation of many physiological and biochemical traits of crops [25-27].

It was previously shown that some of the indices based on the reflectance measured in visible bands are sensitive to a decrease in plant (leaf) water content [28,29], which indicates that the use of VNIR spectroscopy for estimates of changes in leaf water content can be possible. Despite a high number of studies in different crop species related to this topic were published in last few years, the relevant data about useful characteristics related to the leaf water content derived from VNIR hyperspectral records are still scarce.

Therefore, in our study, we examined the changes in spectral reflectance records obtained by proximal sensing of soybean leaves exposed to continuous rapid dehydration. Detailed analyses, realized in fully controlled temperature, light, and humidity conditions, enabled the accurate and reproducible assessment of the specific light reflectance changes attributed solely to the decrease of leaf water content, avoiding the unpredictable nonspecific structural changes due to leaf development and aging as well as the possible scattering of the signal due to light fluctuations occurring in natural sunlight conditions. More specifically, we present correlations of selected spectral reflectance indices (including several water indices) with parameters determining leaf water content, confirming the hypothesis that parameters based on VNIR analysis may serve to reliable estimate the leaf water content in soybean, which may have practical relevance in increasing efficiency of the crop water management. 


\section{Materials and Methods}

\subsection{Plant Material and Experimental Protocol}

Soybean (Glycine max L. Merr., genotype SA-046, China) plants were grown in plastic pots (volume $2 \mathrm{~L}$ ) filled with substrate TS-3 (Klasmann-Deilmann GmbH, Geeste, Germany) containing $140 \mathrm{mg} \mathrm{l}^{-1} \mathrm{~N}$, $160 \mathrm{mg} \mathrm{l}^{-1} \mathrm{P}_{2} \mathrm{O}_{5}, 180 \mathrm{mg} \mathrm{l}^{-1} \mathrm{~K}_{2} \mathrm{O}$, and $100 \mathrm{mg} \mathrm{l}^{-1} \mathrm{Mg}$ and $\mathrm{pH}$ value 6.0. Plants were grown outdoors (in Nitra, Slovakia; $18^{\circ} 06^{\prime} 00.09^{\prime \prime}$ E and 48 $18^{\prime} 15.18^{\prime \prime} \mathrm{N}$, altitude $135 \mathrm{~m}$ ) during the regular vegetation season and irrigation was controlled by gravimetric method, i.e., adding the volume of water until the mass in the pots reached the predetermined value of $80 \%$ volumetric water content. In the R2 growth stage (BBCH stage 65; open flower at one of the two uppermost nodes on the main stem with a fully developed leaf), 10 fully expanded soybean leaves for each experiment were selected from the upper third of plants (each leaf from a different plant). Leaves were kept in water overnight to reach the saturated weight (SW), assumed to be a full leaf turgor state. After SW recording, the reflectance spectra from the adaxial surface of each leaf were measured. Immediately after reflectance measurement, the leaf area was measured by the scan method, using the tiff image of $500 \mathrm{dpi}$ resolution obtained by HP Scanjet G3110 scanner (Hewlett Packard, Palo Alto, CA, USA). The leaf area (LA) was analyzed using ImageJ software version 1.46r (National Institutes of Health, Bethesda, MD, USA). Subsequently, leaves were placed on white paper in a growth chamber, in which the relative air humidity was $40 \%$, the temperature was $23{ }^{\circ} \mathrm{C}$, and the light intensity was $120 \mu \mathrm{mol} \mathrm{m}{ }^{-2} \mathrm{~s}^{-1}$. The weighing of leaves providing the values of fresh weight (FW) and reflectance spectra measurements were repeated 9 times every $20 \mathrm{~min}$. At the end of the experimental protocol, leaves were placed into an oven dryer at $70{ }^{\circ} \mathrm{C}$ for $48 \mathrm{~h}$, and the dry weight (DW) was acquired. An ALS 220-4N analytical balance (Kern \& Sohn $\mathrm{GmbH}$, Balingen, Germany) was used to monitor leaf weight loss.

\subsection{Hyperspectral Reflectance Measurements}

Leaf reflectance spectra in the 325-1075 nm spectral region were measured using a FieldSpec2 spectroradiometer (Analytical Spectral Devices Inc., Boulder, CO, USA) stably positioned in the laboratory at a $90^{\circ}$ field angle and a distance of $120 \mathrm{~mm}$ from the leaf. The spectral resolution of the spectroradiometer was $<3.0 \mathrm{~nm}$ at $700 \mathrm{~nm}$ with wavelength accuracy of $\pm 1.0 \mathrm{~nm}$. Reflectance was induced by light from two 40-watt halogen lamps (Osram 64823 ES FL, Munich, Germany) installed each at a $45^{\circ}$ angle to azimuth. The light spectrum reflected from the adaxial surface of the stably positioned leaf was recorded in the reflectance mode against a black background of cotton cloth. The spectroradiometer was calibrated with a standard white reference panel (Analytical Spectral Devices Inc., Boulder, CO, USA) to determine the reflectance reference standard (Ir). Subsequently, dark signal reading (Id) was performed. Leaf spectral reflectance (Is) measurements were acquired around the central area of the leaf. Reflectance spectra were processed using ViewSpec Pro Version 6.0 software (Analytical Spectral Devices Inc., Boulder, CO, USA). The relative reflectance of leaf (Rs) is given by

$$
\mathrm{Rs}=\frac{\mathrm{Is}-\mathrm{Id}}{\mathrm{Ir}-\mathrm{Id}}
$$

\subsection{Water Status Parameters}

Three parameters, the saturated (SW), fresh (FW), and dry (DW) weights, were used to calculate the water status. Relative water content (RWC, \%) was calculated as

$$
\mathrm{RWC}=\frac{\mathrm{FW}-\mathrm{DW}}{\mathrm{SW}-\mathrm{DW}} \times 100
$$

where SW is the saturated weight of the leaf measured at the beginning of the experimental protocol after overnight water saturation, FW is the fresh weight of the leaf measured during the experimental protocol, and DW is the dry weight of the leaf. 
Equivalent water thickness (EWT, $\mathrm{g} \mathrm{cm}^{-2}$ ) was calculated as

$$
\mathrm{EWT}=\frac{\mathrm{FW}-\mathrm{DW}}{\mathrm{dW} \times \mathrm{LA}}
$$

where LA is the leaf area (in $\left.\mathrm{cm}^{2}\right)$ and $\mathrm{dw}$ is the density of water $\left(1.0 \mathrm{~kg} \mathrm{~m}^{-3}\right)$.

The foliar water content was expressed as percent of dry mass (FWC,$\%$ ) and the foliar water content expressed as percent of total fresh mass $\left(\mathrm{FWC}^{\mathrm{t}}, \%\right)$ was calculated as

$$
\begin{aligned}
& \mathrm{FWC}^{\mathrm{d}}=\frac{\mathrm{FW}-\mathrm{DW}}{\mathrm{DW}} \times 100 \\
& \mathrm{FWC}^{\mathrm{t}}=\frac{\mathrm{FW}-\mathrm{DW}}{\mathrm{FW}} \times 100
\end{aligned}
$$

\subsection{Statistical Analyses}

In the study, two independent sets of measurements ( $\mathrm{n}=2 \times 10$ leaves) were used to training and calibrate the model and subsequently one set of measurement $(\mathrm{n}=10$ leaves) for model validation. All statistics were conducted in Statistica software version 10 (StatSoft Inc., Tulsa, OK, USA). For testing of normal distribution and homogeneity of experimental data were used Kolmogorov-Smirnov and Lavene's statistical tests, respectively. Linear regression between water status parameters (RWC, FWC and EWT) and reflectance vegetation indices as well as between validation and prediction data were performed and Pearson correlation coefficient $\left(\mathrm{r}_{\mathrm{P}}\right)$, coefficient of determination $\left(\mathrm{R}^{2}\right)$ and standard error (SE) were calculated. Finally, the root mean square error (RMSE) between validation and prediction data was calculated as

$$
\text { RMSE }=\sqrt{\frac{1}{n} \sum_{n=1}^{n}\left(y_{i}-\hat{y}_{i}\right)^{2}}
$$

where yi and ŷi are measured value and fit value from the model of individual indices, respectively, and $\mathrm{n}$ is the number of measurements.

\section{Results and Discussion}

The experimental protocol of rapid dehydration of detached individual leaves has often been used in the past for studying functional $[30,31]$ and structural responses to water stress $[32,33]$. The kinetics of water loss during desiccation of detached leaves has been studied in detail in many works. The velocity of water loss is related to features of cellular responses as well as leaf structural characteristics, mainly by leaf mass area (LMA) [32] and cuticular wax composition [30]. In our experiment, mature leaves from the top part of the plant differed in leaf area (mean $6.7 \pm 1.1 \mathrm{~cm}^{2}$ ). Leaf samples were characterized by $6.3 \%$ variation in LMA with a mean level of $44.6 \mathrm{~g} \mathrm{~m}^{-2}$ (Table 1 ). Changes in water loss from soybean leaves under rapid dehydration are shown in Figure 1A. The mean weight of leaves due to loss water declined from $1.39 \pm 0.30 \mathrm{~g}$ in the full turgid state (corresponding to $78.38 \pm 3.28 \%$ foliar water content $\left(\mathrm{FWC}^{\mathrm{t}}\right.$ ) and $0.017 \pm 0.002 \mathrm{~g} \mathrm{~cm}^{-2}$ equivalent water thickness (EWT)) to $0.69 \pm 0.18 \mathrm{~g}$ resulting to $30.65 \pm 8.24 \% \mathrm{FWC}^{\mathrm{t}}$ and $0.006 \pm 0.002 \mathrm{~g} \mathrm{~cm}^{-2}$ EWT, respectively. The relative water content declined from the full turgid state to $35.61 \pm 9.96 \%$ (Table 1). Sample intravariability ( $\mathrm{min}$-max range) decreased under dehydration. The observed dependence between the measured RWC and FWC ${ }^{t}$ was closer $\left(\mathrm{R}^{2}=0.98 ; p<0.001\right)$ than that between RWC and EWT $\left(R^{2}=0.79 ; p<0.001\right)$ (Figure 1B,C). Under drought stress occurred in the field conditions, RWC usually declined up to level 50-60\% [2-4]. Water loss from the tissues during plant dehydration resulted to increase of leaf/canopy reflectance [21,34-36]. However, there are still discussions whether the changes measured in the plant reflectance can be able to capture a small decline of water content during presymptomatic phase of water stress $[11,14,23,36]$. 
Table 1. Characterization of soybean leaves used for calibration in the terminal phase of rapid dehydration.

\begin{tabular}{cccccc}
\hline & $\begin{array}{c}\text { LA } \\
\left(\mathbf{c m}^{\mathbf{2}}\right)\end{array}$ & $\begin{array}{c}\text { LMA (g } \\
\mathbf{m}^{-\mathbf{2}} \mathbf{)}\end{array}$ & RWC (\%) & FWC $\mathbf{~ ( \% )}$ & EWT $\left(\mathbf{g ~ c m}^{-\mathbf{2}}\right)$ \\
\hline Mean & 6.639 & 44.574 & 35.606 & 30.653 & 0.006 \\
S.D. & 1.099 & 2.822 & 9.960 & 8.240 & 0.002 \\
Min & 4.895 & 41.991 & 17.170 & 13.705 & 0.003 \\
Max & 8.322 & 49.991 & 47.720 & 46.405 & 0.007 \\
C.V. & 16.554 & 6.331 & 27.720 & 26.880 & 25.150 \\
\hline
\end{tabular}

LA—leaf area; LMA—leaf mass area; RWC-relative water content; FWC —foliar water content as percent of total fresh mass; EWT—equivalent water thickness; S.D.—standard deviation; Min—minimum; Max—maximum; C.V.-coefficient of variation (\%), $\mathrm{n}=20$.
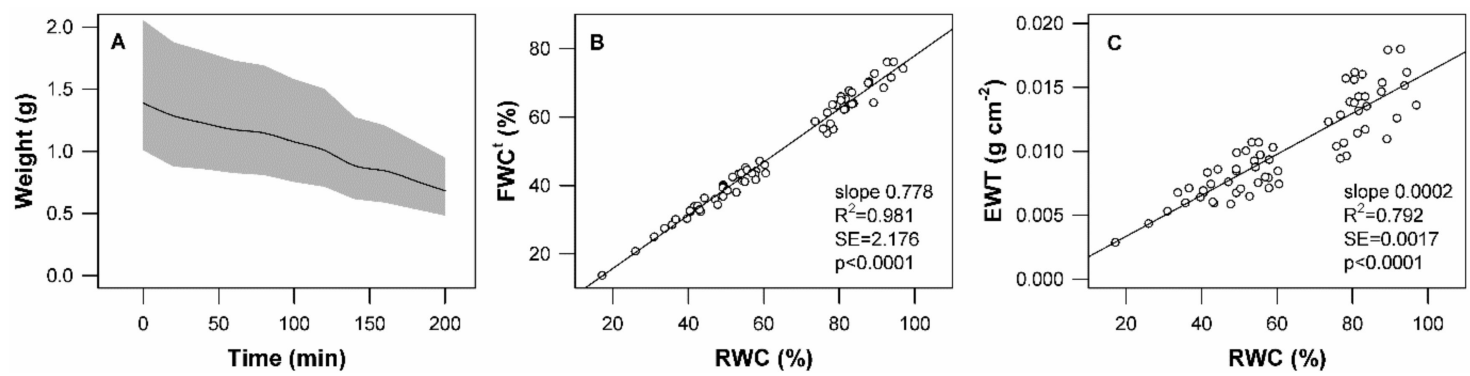

Figure 1. The mean value of soybean leaf weight loss (solid line, gray area represented difference between min-max values of leaf weight, $n=20)(A)$, linear regressions between relative water content (RWC) and fuel water content $\left(F W C^{t}\right)(B)$, and equivalent water thickness (EWT) (C) of soybean leaf under rapid dehydration $(n=162)$. The slope of function, the determination coefficient $\left(R^{2}\right)$, the standard error (SE) and probability $(p)$ are inserted inside graphs.

Figure 2A shows the mean spectra of leaves for various ranges of RWC. Leaves with high RWC, as well as FWC and EWT, have relatively low reflectance at 680-700 nm and 750-1000 nm.
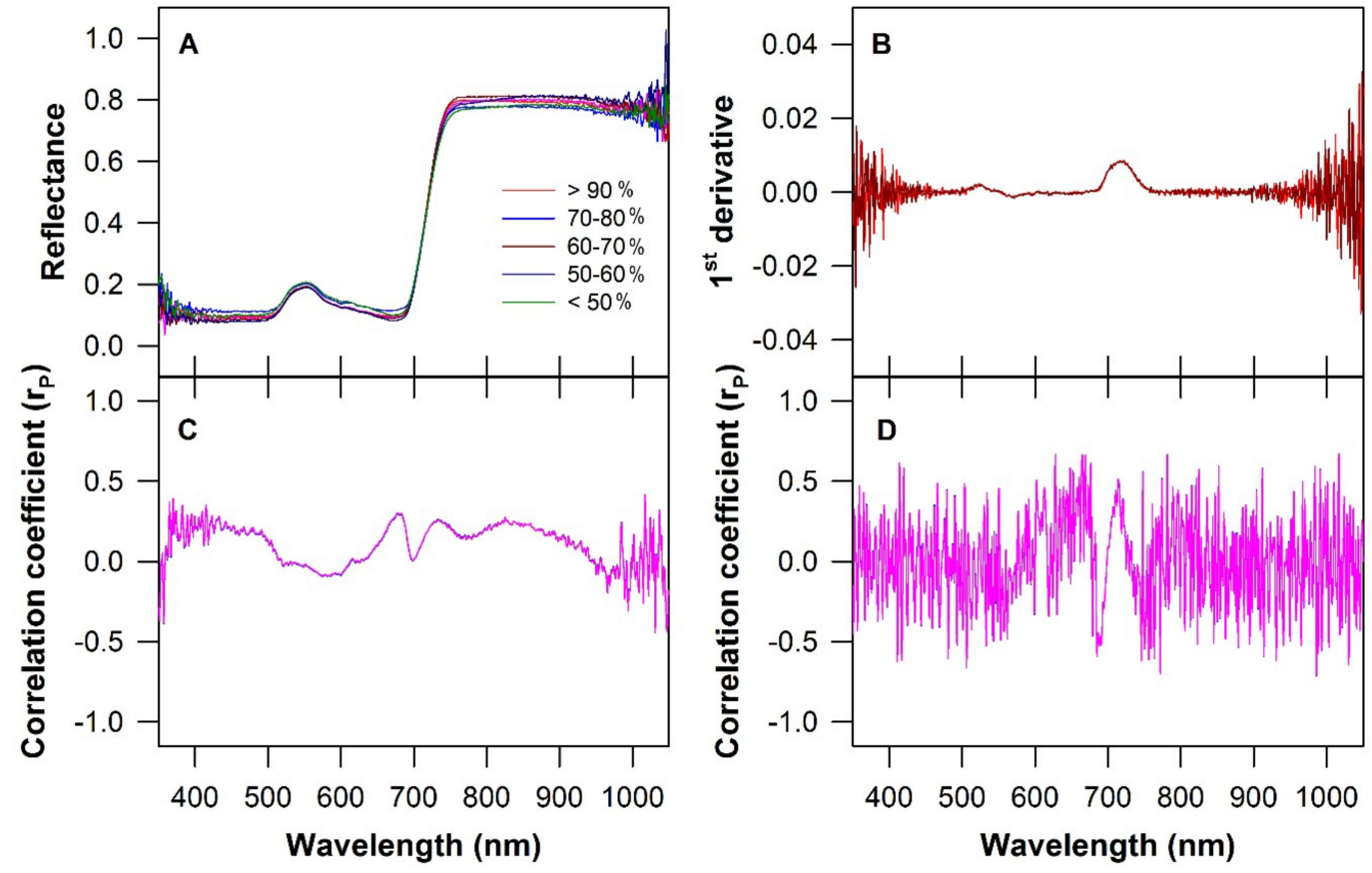

Figure 2. Reflectance spectra signatures (A), the first derivative of reflectance (B), correlation coefficient $\left(r_{P}\right)$ of relationship between relative water content (RWC; \%) and reflectance spectra $(C)$, and first derivative of reflectance (D). Different colored lines represented intervals of RWC (see the legend). 
The course of the reflectance spectrum in the UV/VIS/NIR spectral region is predominantly affected by pigment absorption (mainly by chlorophyll molecules) [34] and the weak absorption of water at the $970 \mathrm{~nm}$ band [9,12], as well as the structural characteristics of the leaf.

Dehydration of leaves caused changes in optical properties with increasing relative reflectance at wavelengths between 580 and $700 \mathrm{~nm}$. However, many published studies report inconsistent changes in leaf reflectance during dehydration, including a general increase [21,35,36], a decrease [37], and nonsignificant changes in reflectance [38,39]. Many of these studies have been performed on the canopy level at different plant growth stages, canopy structures, and plant leaf anatomy and thickness, as well as external atmospheric variability. For these reasons, we used an approach with precisely defined experimental conditions and leaf properties. In our study, a water loss below $50 \%$ of RWC led to an almost complete reduction in the water absorption band at approximately $970 \mathrm{~nm}$. These results were more pronounced after the first derivative of relative reflectance (Figure 2B). Figure 2C shows the course of Pearson's correlation coefficients $\left(\mathrm{r}_{\mathrm{P}}\right)$ in the relationship between wavelength-dependent relative reflectance values and RWC. Maximal values of $r_{P}$ were not higher than 0.40 in the spectral range of 400 to $1000 \mathrm{~nm}$ (marginal areas of spectral range below $400 \mathrm{~nm}$ and above $1000 \mathrm{~nm}$ were characterized by high scattering of raw relative reflectance). The maximal positive values of $r_{P}$ were observed at $682 \mathrm{~nm}\left(r_{P}=0.38\right), 738 \mathrm{~nm}\left(r_{P}=0.26\right)$, and $825 \mathrm{~nm}\left(r_{P}=0.27\right)$. On the other hand, in the wavelength ranges of $520-550 \mathrm{~nm}, 610-630 \mathrm{~nm}, 700 \mathrm{~nm}$, and 750-760 nm, a minimal (approximately $0.0)$ correlation was observed between the relative reflectance of the leaf and RWC. The maximal negative values of $r_{P}$ between both parameters were observed at $580-585 \mathrm{~nm}\left(r_{P}=-0.14\right), 970-975$ $n m\left(r_{P}=-0.22\right)$, and $994 n m\left(r_{P}=-0.31\right)$ (Figure 2C). Figure 2D shows the course of $r_{P}$ in the relationship between the wavelength-dependent first derivative of the relative reflectance values and RWC. The course of this relationship confirmed an interesting spectral reflectance area affected by the water content in leaves in the range of 550 to $580 \mathrm{~nm}$ and 630 to $750 \mathrm{~nm}$ (Figure 2D). Vegetative indices calculated from relative reflectance in the green spectral region showed a significant negative correlation with water content (expressed as RWC and EWT). Turgor loss under cell dehydration is associated with a change in cell volume (shrinking) [40,41], mainly when the cell wall is characterized by a high modulus of elasticity [42]. Peñuelas and coworkers [12,43] showed that cell wall elasticity in response to water stress may be monitored based on changes in leaf reflectance. Moreover, the shrinking of mesophyll cells leads to a passive increase in chlorophyll content, and it has been associated with an enhancement of reflectance in the spectral region of 490 to $510 \mathrm{~nm}$ [17].

The results of the correlation range of $\mathrm{r}_{\mathrm{P}}$ between RWC, $\mathrm{FWC}^{\mathrm{t}}, \mathrm{FWC}^{\mathrm{d}}$, and EWT and the vegetative indices are shown in Figure 3. Dark green represents higher positive values of $r_{P}$, dark red represents higher negative values, and yellow represents the lower values of $r_{P}$. The most commonly used vegetation indices are summarized in Table S1. The highest positive correlations were observed for relationships between PRI and RWC, FWC ${ }^{t}$ and EWT $\left(r_{P}=0.786,0.815\right.$, and 0.860, respectively; $p<0.0001)$. In the case of correlation between RWC and vegetation reflectance indices, the observed range of $\mathrm{r}_{\mathrm{P}}$ values $0.50 \rightarrow 0.59(p<0.01)$ were for PRI1 $>\mathrm{fWBI}>\mathrm{WI}>\mathrm{NPQI}$; the range of $\mathrm{r}_{\mathrm{P}}$ values $0.40 \rightarrow 0.49(p<0.01)$ were for PSRI $>$ NGRR; the range of $\mathrm{r}_{P}$ values $0.30 \rightarrow 0.39(p<0.05)$ were for EVI $>$ SIPI $>$ RGI1 $>$ BGI1 $>$ BGI; the range of $\mathrm{r}_{\mathrm{P}}$ values $0.20 \rightarrow 0.29(p<0.05)$ were for ARI2 $>$ ARI1 $>$ BRI $>$ SR3 $>$ BRI2 $>$ Lic1 $>$ RGI; the range of $r_{P}$ values $0.10 \rightarrow 0.19(p>0.05)$ were for BRI1 $>$ SR4 $>$ Vog1 $>$ Lic2 $>\operatorname{Vog} 2>$ GMI1; the range of $r_{P}$ values $0.00 \rightarrow 0.09(p>0.05)$ were for GMI2 $>$ mNDVI $>$ ZM $>$ SRPI $>$ NDVI2 $>$ NPCI; the range of $\mathrm{r}_{\mathrm{P}}$ values $-0.01 \rightarrow-0.09$ were for DVI $>$ Crt2 $>$ SR2 $>$ Vog $>$ TVI; the range of $\mathrm{r}_{\mathrm{P}}$ values $-0.10 \rightarrow-0.19(p>0.05)$ were for SIPI $>$ CRI $2>\mathrm{RDVI}>\mathrm{TVI} 1>\mathrm{CRI} 1>\mathrm{MCARI} 1>$ MTVI1 $>$ NDVI $>$ MSR $>$ SR $>$ OSAVI $>$ MTVI3; the range of $\mathrm{r}_{P}$ values $-0.20 \rightarrow-0.29(p<0.05)$ were for NDVI3 $>$ NDVI1 $>$ RVI $>$ NDVI4 $>$ Crt3 $>$ RBI; the range of $\mathrm{r}_{\mathrm{P}}$ values $-0.30 \rightarrow-0.39(p<0.01)$ were for Crt1 $>$ TCARI $>$ MCARI $>$ MCARI2 > MTVI2 > GRR; the range of $\mathrm{r}_{P}$ values $-0.40 \rightarrow-0.49$ $(p<0.01)$ were for GI > NGRI1; and the range of $r_{P}$ values $-0.50 \rightarrow-0.59(p<0.001)$ were for PRI3 > WBI. The highest negative correlation was observed for relation between CUR and RWC $\left(\mathrm{r}_{\mathrm{P}}=-0.721\right.$; 
$p<0.0001)$. The correlations between spectral reflectance vegetation indices and EWT were higher than those between RWC, FWC ${ }^{t}$, and FWC ${ }^{d}$ (Figure 3).

For the calculation of vegetative indices, we used the standard, and in recent years, frequently used, formulation. Vegetative indices related to structural traits were poorly correlated with water content parameters. Similar observations have been made in experiments with different plant species, including soybean $[11,14,44,45]$. However, several studies have shown that vegetation indices measuring the structural traits of plants have a strong correlation with plant water content. These observations originate, however, mainly from field experiments [11,15,46].

\begin{tabular}{|c|c|c|c|c|c|c|c|c|c|c|c|}
\hline & RWC & $F W C^{d}$ & $\mathrm{FWC}^{\mathrm{t}}$ & EWT & & RWC & $F W C^{d}$ & $F W c^{t}$ & EWT & & \\
\hline \multicolumn{5}{|c|}{ Water content indices } & \multicolumn{5}{|c|}{ Green biomass indices (continued) } & \multirow[b]{2}{*}{ scale } & \multirow[b]{2}{*}{$r_{p}$} \\
\hline WBI & & & & & mNDVI & & & & & & \\
\hline WI & & & & & MTVI1 & & & & & & 1.0 \\
\hline fWBI & & & & & MTVI2 & & & & & & 0.9 \\
\hline \multicolumn{5}{|c|}{ Green biomass indices } & MTVI3 & & & & & & 0.8 \\
\hline GI & & & & & RDVI & & & & & & 0.7 \\
\hline RGI & & & & & MSR & & & & & & 0.6 \\
\hline RGI1 & & & & & TVI & & & & & & 0.5 \\
\hline BGI & & & & & TVI1 & & & & & & 0.4 \\
\hline BGI1 & & & & & Vog1 & & & & & & 0.3 \\
\hline BRI & & & & & Vog2 & & & & & & 0.2 \\
\hline BRI1 & & & & & CUR & & & & & & 0.1 \\
\hline BRI2 & & & & & EVI & & & & & & 0.0 \\
\hline RVI & & & & & PSRI & & & & & & -0.1 \\
\hline GRR & & & & & OSAVI & & & & & & -0.2 \\
\hline SR & & & & & \multicolumn{5}{|c|}{ Chlorophyll content indices } & & -0.3 \\
\hline SR2 & & & & & PRI & & & & & & -0.4 \\
\hline SR3 & & & & & PRI1 & & & & & & -0.5 \\
\hline SR4 & & & & & PRI3 & & & & & & -0.6 \\
\hline RBI & & & & & ZM & & & & & & -0.7 \\
\hline DVI & & & & & SIPI & & & & & & -0.8 \\
\hline SRPI & & & & & SIPI1 & & & & & & -0.9 \\
\hline Crt1 & & & & & TCARI & & & & & & -1.0 \\
\hline crt2 & & & & & MCARI & & & & & & \\
\hline Crt3 & & & & & MCARI1 & & & & & & \\
\hline Lic1 & & & & & MCARI2 & & & & & & \\
\hline Lic2 & & & & & $\mathrm{NPCl}$ & & & & & & \\
\hline Vog & & & & & NPQI & & & & & & \\
\hline GMI1 & & & & & \multicolumn{5}{|c|}{ Anthocyanin content indices } & & \\
\hline GMI2 & & & & & ARI1 & & & & & & \\
\hline NGRR & & & & & ARI2 & & & & & & \\
\hline NGRI1 & & & & & \multicolumn{5}{|c|}{ Carotenoids content indices } & & \\
\hline NDVI & & & & & CRI1 & & & & & & \\
\hline NDVI1 & & & & & CRI2 & & & & & & \\
\hline NDVI2 & & & & & PRI & & & & & & \\
\hline NDVI3 & & & & & PRI1 & & & & & & \\
\hline NDVI4 & & & & & PRI3 & & & & & & \\
\hline
\end{tabular}

Figure 3. Correlogram of Pearson's correlation coefficient $\left(\mathrm{r}_{\mathrm{P}}\right)$ between calculated vegetation indices from reflectance spectra and relative water content (RWC), fuel water content as percent of total fresh mass $\left(F W C^{t}\right)$, fuel water content as percent of dry mass $\left(\mathrm{FWC}^{\mathrm{d}}\right)$, and equivalent water thickness (EWT).

The functional relationships of the previously selected widely used WI, fWBI, NDVI, PRI, and CUR vegetation indices to water content parameters are presented in Figure 4. The WI and fWBI water indices showed positive correlations with RWC, FWC ${ }^{t}$, and EWT in the range of $\mathrm{r}_{\mathrm{P}} 0.452$ (Figure 4D) to 0.617 (Figure 4 C) $(p<0.001)$. Similar correlation levels of these indices to water content have been observed in many previous studies $[11,14]$. Using water potential as a criterion of the water 
status of field grown plants, Pôças et al. [15] observed correlations with standard vegetation indices at a level near 0.67. It turns out that reflectance in water bands is likely lower at the canopy level than in individual leaves, mainly for higher overall canopy water content as a result of a larger biomass layer thickness [11]. The highest positive correlation was observed between PRI and EWT at the level of $r_{P}=0.860(p<0.0001)$ (Figure 4L). The highest negative correlation was observed between CUR and RWC at the level of $r_{P}=0.721(p<0.0001)$ (Figure $\left.4 \mathrm{M}\right)$. On the other hand, no correlation was observed between the NDVI and water content parameters $\left(r_{P}=-0.138,-0.134\right.$ and -0.071 for RWC, $\mathrm{FWC}^{\mathrm{t}}$, and EWT, respectively; $p>0.2$ ) (Figure $4 \mathrm{G}-\mathrm{I}$ ). It has been well documented from previous laboratory and canopy experiments that the PRI is highly affected by light-induced, diurnal changes in xanthophyll transformation [11,28,29,47].
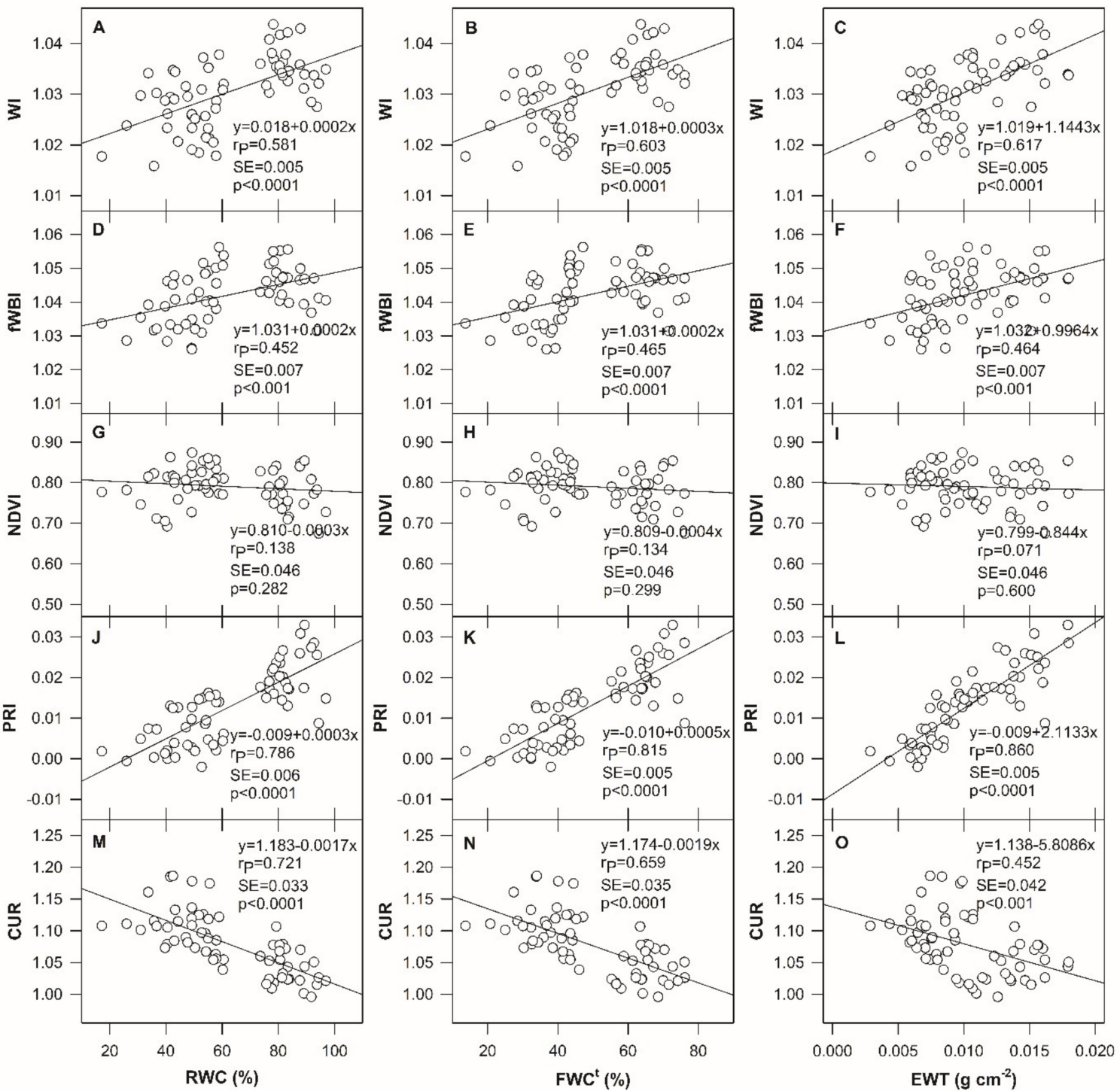

Figure 4. Relationship between water index (WI) (A,B,C), floating position water band (fWBI) $(\mathrm{D}, \mathrm{E}, \mathrm{F})$, normalized difference vegetation index (NDVI) $(\mathrm{G}, \mathrm{H}, \mathrm{I})$, photochemical reflectance index (PRI) $(\mathbf{J}, \mathbf{K}, \mathbf{L})$, curvature (CUR) $(\mathbf{M}, \mathbf{N}, \mathbf{O})$ and relative water content (RWC) $(\mathbf{A}, \mathbf{D}, \mathbf{G}, \mathbf{J}, \mathbf{M})$, fuel water content $\left(F_{W C}\right)(\mathbf{B}, \mathbf{E}, \mathbf{H}, \mathbf{K}, \mathbf{N})$, and equivalent water thickness (EWT) $(\mathbf{C}, \mathbf{F}, \mathbf{I}, \mathbf{L}, \mathbf{O})$. Solid lines represent the linear relationship between parameters. Data were used for calibration process. Linear equations, Pearson's correlation coefficients $\left(\mathrm{r}_{\mathrm{P}}\right)$, standard error $(\mathrm{SE})$, and probability $(p)$ are inserted inside graphs.

Using training data for creating the model, the predictions of RWC, FWC ${ }^{t}$, and EWT from validation set reflectance data were conducted. Statistical analyses of linear regressions between 
gravimetrically measured and predicted values of different water content parameters obtained by calculation of selected reflectance vegetation indices measured during rapid dehydration of individual soybean leaves are shown in Figure 5. To confirm the strength of the prediction of water content by spectral indices, we calculated Pearson's correlation coefficients $\left(\mathrm{r}_{\mathrm{P}}\right)$, root mean square error (RMSE), standard error (SE) and $p$-values. Higher $\mathrm{r}_{\mathrm{P}}$ and lower RMSE indicate a better accuracy of the spectral indices for water content determination. The RMSE for predictive performance of RWC from WBI was found at level 16.3\% ( $\left.\mathrm{r}_{\mathrm{P}}=0.581 ; p<0.001\right)$ (Figure 5A). Figure 5B,C show better RMSEs for FWC and EWT. The observed RMSEs for leaf water content parameters calculated from PRI measurements were $12.4 \%\left(r_{P}=0.786\right), 9.1 \%\left(r_{P}=0.736\right)$, and $0.002\left(r_{P}=0.860\right)$ for RWC, FWC ${ }^{t}$, and EWT $(p<0.001)$, respectively (Figure 5J-L).
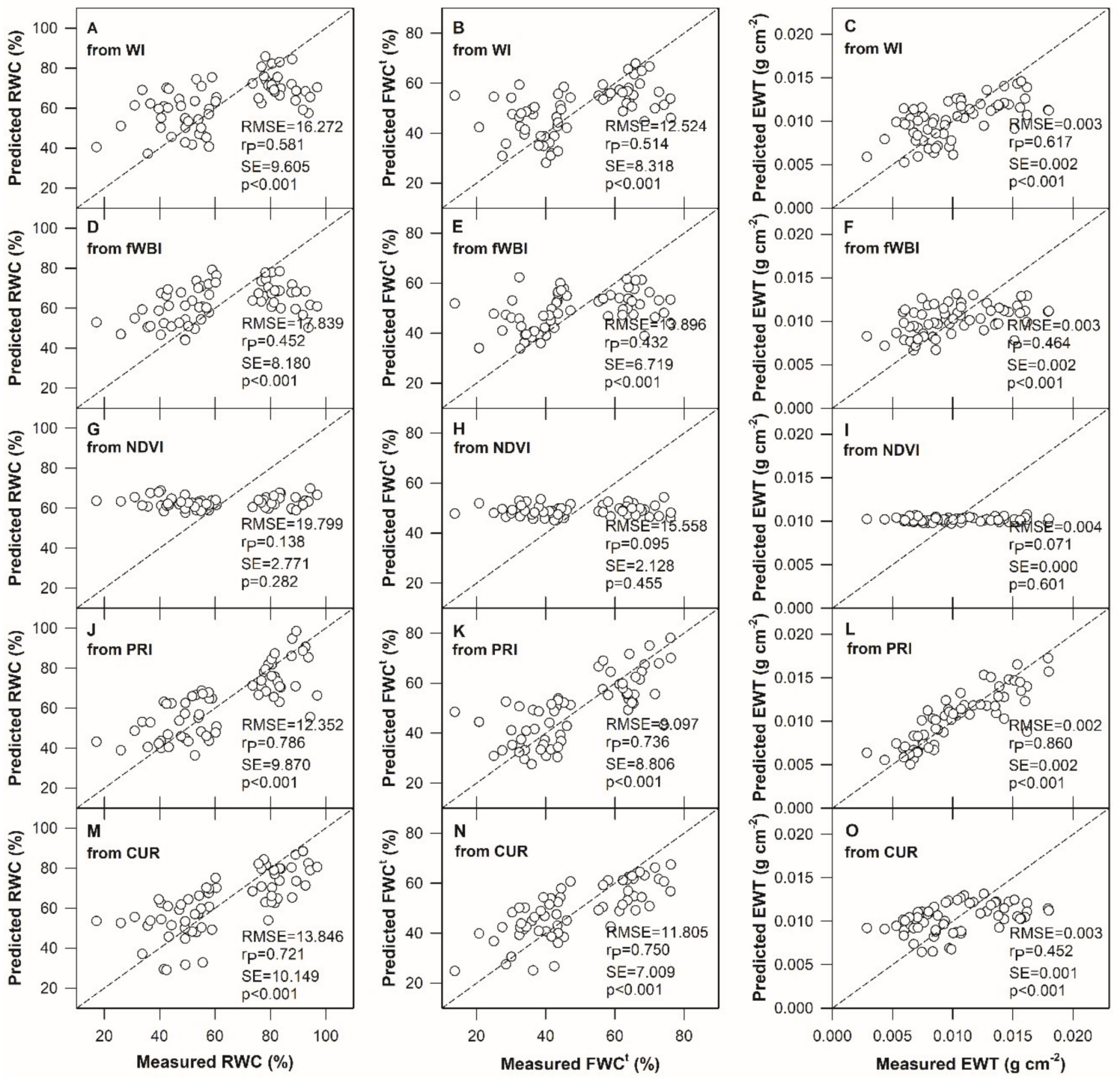

Figure 5. Predicted relative water content $(\mathrm{RWC})(\mathbf{A}, \mathbf{D}, \mathbf{G}, \mathbf{J}, \mathbf{M})$, fuel water content $\left(\mathrm{FWC}^{\mathrm{t}}\right)(\mathbf{B}, \mathbf{E}, \mathbf{H}, \mathbf{K}, \mathbf{N})$, and equivalent water thickness (EWT) $(\mathbf{C}, \mathbf{F}, \mathbf{I}, \mathbf{L}, \mathbf{O})$ from calculated reflectance vegetation indices water index (WI) (A,B,C), floating position water band (fWBI) (D,E,F), normalized difference vegetation index (NDVI) $(\mathbf{G}, \mathbf{H}, \mathbf{I})$, photochemical reflectance index (PRI) $(\mathbf{J}, \mathbf{K}, \mathbf{L})$, and curvature (CUR) $(\mathbf{M}, \mathbf{N}, \mathbf{O})$ versus measured data for validation process. Root mean square error (RMSE), Pearson's correlation coefficients $\left(\mathrm{r}_{\mathrm{P}}\right)$, standard error $(\mathrm{SE})$, and probability $(p)$ are inserted inside graphs. Dashed lines represent 1:1 line. 
The use of NDVI to predict water content was not appropriate because $\mathrm{r}_{\mathrm{P}}$ (and RMSE) had been detected at levels of $0.138(12.4 \%), 0.095(15.6 \%)$, and $0.071\left(0.004 \mathrm{~g} \mathrm{~cm}^{-2}\right)$ for RWC, FWC ${ }^{\mathrm{t}}$, and EWT, respectively (Figure 5G-I). We have shown earlier that the rapid loss of water from the leaf did not affect the reflectance in the wavelength range of the red edge (Figures 2 and $4 \mathrm{G}-\mathrm{I}$ ). The data presented in Figure 5 confirmed the observation of closer relationships of the measured reflectance vegetation parameters with EWT than with $\mathrm{FWC}^{\mathrm{t}}$ and RWC. This result, acquired from the rapid dehydration of soybean leaves, again confirmed that the RWC was not a good parameter for evaluating leaf water content based on the reflection assessment (Figures 4 and 5). These results confirmed that sensitive hyperspectral sensors and the use of appropriate vegetation indices in nondestructive and remote sensing may become a simple tool for identifying plant health in the management of modern plant production. Although currently there are other nondestructive evaluation methods of water content in plants, especially plant/crop thermography and thermal imaging, suitably chosen spectral reflectance vegetation indices allow comprehensively identify and assess the impact of environmental stress on plants. It must be also taken into an account that in field conditions, water stress may be accompanied by changes in other leaf characteristics, which in turn would also affect the reflectance characteristics of a leaf in addition to water content of leaf tissues. Therefore, in the next step, more complex experiments and comparative studies should be conducted to fully understand the impact of biological changes in the tissues of plants, taking into an account detailed data on the water potential decrease during the initial stages of stress sensing by the optical signals.

\section{Conclusions}

This study shows that precise measurement of leaf reflectance allows the estimation of water content in plants under rapid dehydration. We observed a strong correlation between two parameters of water content (EWT and FWC) and the PRI, WI, and WBI reflectance indices. Statistical analyses between validated and predicted dataset values confirmed that PRI is a good index for estimating leaf water content. Under rapid dehydration of soybean leaves, the reflectance parameters were less sensitive if the water status was evaluated as RWC. This study confirmed that the bulk volume of water inside the leaf (mainly characterized as EWT) is a much better indicator of water absorption features. The study indicated that nondestructive analysis from hyperspectral reflectance measurements could be successfully used for monitoring water content parameters in soybean leaves.

Supplementary Materials: The following are available online at http:/ /www.mdpi.com/2073-4441/11/3/443/s1, Table S1: List of vegetation indices using in the study.

Author Contributions: Conceptualization, M.B., V.B., and M.Z.; Data Curation, O.S.; Formal Analysis, M.K.; Funding Acquisition, M.B. and V.B.; Investigation, M.K., O.S., and M.Z.; Methodology, M.K.; Project Administration, M.B.; Resources, P.H.; Supervision, M.Z.; Validation, V.B., P.H., and M.Z.; Visualization, M.K. and O.S.; Writing-Original Draft, M.K.; Writing—Review \& Editing, M.B., V.B., P.H., and M.Z.

Funding: This research was funded by grant numbers APVV-15-0562, APVV-15-0721, and VEGA-1-0831-17 and by the European Community under project No. 26220220180.

Conflicts of Interest: The authors declare no conflicts of interest.

\section{References}

1. Boyer, J.S. Plant productivity and environment. Science 1982, 218, 443-448. [CrossRef] [PubMed]

2. Sinclair, T.R. Challenges in breeding for yield increase for drought. Trends Plant Sci. 2011, 16, $289-293$. [CrossRef] [PubMed]

3. Blum, A. Drought resistance-Is it really a complex trait? Funct. Plant Biol. 2011, 38, 753-757. [CrossRef]

4. Specht, J.E.; Hume, D.J.; Kumudini, S.V. Soybean yield potential—A genetic and physiological perspective. Crop Sci. 1999, 39, 1560-1570. [CrossRef]

5. Mutava, R.N.; Prince, S.J.K.; Syed, N.H.; Song, L.; Chen, W.; Nguyen, H.T. Understanding abiotic stress tolerance mechanisms in soybean: A comparative evaluation of soybean response to drought and flooding stress. Plant Physiol. Biochem. 2015, 86, 109-120. [CrossRef] [PubMed] 
6. Bartlett, M.K.; Klein, T.; Jansen, S.; Choat, S.; Sack, L. The correlations and sequence of plant stomatal, hydraulic, and wilting responses to drought. Proc. Natl. Acad. Sci. USA 2016, 113, 13098-13103. [CrossRef] [PubMed]

7. Farquhar, G.D.; Sharkey, T.D. Stomatal conductance and photosynthesis. Annu. Rev. Plant Physiol. 1982, 33, 317-345. [CrossRef]

8. Zivcak, M.; Brestic, M.; Balatova, Z.; Drevenakova, P.; Olsovska, K.; Kalaji, H.M.; Yang, X.; Allakhverdiev, S.I. Photosynthetic electron transport and specific photoprotective responses in wheat leaves under drought stress. Photosynth. Res. 2013, 117, 529-546. [CrossRef] [PubMed]

9. Jones, H.G. Irrigation scheduling: Advances and pitfalls of plant-based methods. J. Exp. Bot. 1994, 55, 2427-2436. [CrossRef] [PubMed]

10. Kramer, P.J.; Boyer, J.S. Water Relations in Plants and Soils; Academic Press: San Diego, CA, USA, 1995; 495p.

11. Rodríguez-Pérez, J.R.; Riaño, D.; Carlisle, E.; Ustin, S.; Smart, D.R. Evaluation of hyperspectral indexes to detect grapevine water status in vineyards. Am. J. Enol. Vitic. 2007, 58, 302-317.

12. Peñuelas, J.; Filella, I.; Biel, C.; Serrano, L.; Savé, R. The reflectance at the $950-970 \mathrm{~nm}$ region as an indicator of plant water status. Int. J. Remote Sens. 1993, 14, 1887-1905. [CrossRef]

13. Haboudane, D.; Miller, J.R.; Tremblay, N.; Zarco-Tejada, P.J.; Dextraze, L. Integrated narrow-band vegetation indices for prediction of crop chlorophyll content for application to precision agriculture. Remote Sens. Environ. 2002, 81, 416-426. [CrossRef]

14. Rallo, G.; Minacapilli, M.; Ciraolo, G.; Provenzano, G. Detecting crop water status in mature olive groves using vegetation spectral measurements. Biosyst. Eng. 2014, 128, 52-68. [CrossRef]

15. Pôças, I.; Rodrigues, A.; Gonçalves, S.; Costa, P.M.; Gonçalves, I.; Pereira, L.S.; Cunha, M. Predicting grapevine water status based on hyperspectral reflectance vegetation indices. Remote Sens. 2015, 7, 16460-16479. [CrossRef]

16. Sytar, O.; Brestic, M.; Zivcak, M.; Olsovska, K.; Kovar, M.; Shao, H.; He, X. Applying hyperspectral imaging to explore natural plant diversity towards improving salt stress tolerance. Sci. Total Environ. 2017, 157, 90-99. [CrossRef] [PubMed]

17. Peñuelas, J.; Inoue, Y. Reflectance indices indicative of changes in water and pigment contents of peanut and wheat leaves. Photosynthetica 1999, 36, 355-360. [CrossRef]

18. Ceccato, P.; Flasse, S.; Tarantola, S.; Jacquemoud, S.; Crégoire, J.-M. Detecting vegetation leaf water content using reflectance in the optical domain. Remote Sens. Environ. 2001, 77, 22-33. [CrossRef]

19. Yi, Q.-X.; Bao, A.-M.; Wang, Q.; Zhao, J. Estimation of leaf water content in cotton by means of hyperspectral indices. Comput. Electron. Agric. 2013, 90, 144-151. [CrossRef]

20. Colombo, R.; Busetto, L.; Meroni, M.; Rossini, M.; Panigada, C. Optical remote sensing of vegetation water content. In Hyperspectral Remote Sensing of Vegetation; Thenkabail, P.S., Lyon, J.G., Huete, A., Eds.; CRC Press: Boca Raton, FL, USA, 2012; pp. 227-244.

21. Ripple, W.J. Spectral reflectance relationships to leaf water stress. J. Photogramm. Remote Sens. 1986, 52, 1669-1675.

22. Peñuelas, J.; Pinol, J.; Ogaya, R.; Filella, I. Estimation of plant water concentration by the reflectance water index WI (900/970). Int. J. Remote Sens. 1997, 18, 2869-2875. [CrossRef]

23. Kim, D.M.; Zhang, H.; Zhou, H.; Du, T.; Wu, Q.; Mockler, T.C.; Berezin, M.Y. Highly sensitive image-derived indices of water-stressed plants using hyperspectral imaging in SWIR and histogram analysis. Sci. Rep. 2015, 5, 15919. [CrossRef] [PubMed]

24. Strachan, I.B.; Pattey, E.; Boisvert, J.B. Impact of nitrogen and environmental conditions on as detected by hyperspectral reflectance. Remote Sens. Environ. 2002, 80, 213-224. [CrossRef]

25. Wahabzada, M.; Mahlein, A.-K.; Bauckhage, C.; Steiner, U.; Oerke, E.-C.; Kersting, K. Plant phenotyping using probabilistic topic models: Uncovering the hyperspectral language of plants. Sci. Rep. 2016, 6, 22482. [CrossRef] [PubMed]

26. Maimaitiyiming, M.; Ghulam, A.; Bozzolo, A.; Wilkins, J.L.; Kwasniewski, M.T. Early Detection of Plant Physiological Responses to Different Levels of Water Stress Using Reflectance Spectroscopy. Remote Sens. 2017, 9, 745. [CrossRef]

27. Silva-Perez, V.; Molero, G.; Serbin, S.P.; Condon, A.G.; Reynolds, M.P.; Furbank, R.T.; Evans, J.R. Hyperspectral reflectance as a tool to measure biochemical and physiological traits in wheat. J. Exp. Bot. 2018, 69, 483-496. [CrossRef] [PubMed] 
28. Suárez, L.; Zarco-Tejada, P.J.; Sepulcre-Cantó, G.; Pérez-Priego, O.; Miller, J.R.; Jiménez-Muñoz, J.C.; Sobrino, J. Assessing canopy PRI for water stress detection with diurnal airborne imagery. Remote Sens. Environ. 2008, 112, 560-575. [CrossRef]

29. Suárez, L.; Zarco-Tejada, P.J.; Berni, J.A.J.; Gonzáles-Dugo, V.; Fereres, E. Modelling PRI for water stress detection using radiative transfer models. Remote Sens. Environ. 2009, 113, 730-744. [CrossRef]

30. Aharoni, N. Relationship between leaf water status and endogenous ethylene in detached leaves. Plant Physiol. 1978, 61, 658-662. [CrossRef] [PubMed]

31. Peñuelas, J.; Filella, I.; Gamon, J.A. Assessment of photosynthetic radiation-use efficiency with spectral reflectance. New Phytol. 1995, 131, 291-296. [CrossRef]

32. Blackman, C.J.; Brodribb, T.J. Two measures of leaf capacitance: Insights into the water transport pathway and hydraulic conductance in leaves. Funct. Plant Biol. 2011, 38, 118-126. [CrossRef]

33. Ristic, Z.; Jenks, M.A. Leaf cuticle and water loss in maize lines differing in dehydration avoidance. J. Plant Physiol. 2002, 159, 645-651. [CrossRef]

34. Carter, G.A.; Knapp, A.K. Leaf optical properties in higher plants: Linking spectral characteristics to stress and chlorophyll concentration. Am. J. Bot. 2001, 88, 677-684. [CrossRef] [PubMed]

35. Carter, G.A. Ratios of leaf reflectance in narrow wavebands as indicators of plant stress. Int. J. Remote Sens. 1994, 15, 697-703. [CrossRef]

36. Seeling, H.-D.; Hoehn, A.; Stodieck, L.S.; Klaus, D.M.; Adams III, W.A.; Emery, W.J. The assessment of water content using leaf reflectance ratios in the visible, near-, and short-wave-infrared. Int. J. Remote Sens. 2008, 29, 3701-3713. [CrossRef]

37. Jackson, R.D.; Ezra, C.E. Spectral response of cotton to suddenly induced water stress. Int. J. Remote Sens. 1985, 6, 177-185. [CrossRef]

38. Cohen, W.B. Temporal versus spatial variation in leaf reflectance under changing water stress conditions. Int. J. Remote Sens. 1991, 12, 1865-1876. [CrossRef]

39. Moore, J.P.; Vicré-Gibouin, M.; Farrant, J.M.; Driouich, A. Adaptations of higher plant cell walls to water loss: Drought vs desiccation. Physiol. Plant. 2008, 134, 237-245. [CrossRef] [PubMed]

40. Riggs, G.A.; Running, S.W. Detection of canopy water stress in conifers using airborne imaging spectrometer. Remote Sens. Environ. 1991, 35, 51-68. [CrossRef]

41. Canny, M.J.; Huang, C.X. Leaf water content and palisade cell size. New Phytol. 2006, 170, 75-85. [CrossRef] [PubMed]

42. Scoffoni, C.; Vuong, C.; Diep, S.; Cochard, H.; Sack, L. Leaf shrinkage with dehydration: Coordination with hydraulic vulnerability and drought tolerance. Plant Physiol. 2014, 164, 1772-1788. [CrossRef] [PubMed]

43. Peñuelas, J.; Filella, I.; Serrano, L. Cell wall elasticity and water index (R970/R900 nm) in wheat under different nitrogen availabilities. Int. J. Remote Sens. 1996, 2, 373-382. [CrossRef]

44. Inoue, Y.; Morinaga, S.; Shibayama, M. Non-destructive estimation of water status of intact crop leaves based on spectral reflectance measurements. Jpn. J. Crop Sci. 1993, 62, 462-469. [CrossRef]

45. Zarco-Tejada, P.J.; Berjón, A.; López-Lozano, R.; Miller, J.R.; Matín, P.; Cachorro, V.; Gonzáles, M.R.; de Frutos, A. Assessing vineyard condition with hyperspectral indices: Leaf and canopy reflectance simulation in a row-structured discontinuous canopy. Remote Sens. Environ. 2005, 99, 271-287. [CrossRef]

46. Zygielbaum, A.I.; Gitelson, A.A.; Arkebauer, T.J.; Rundquist, D.C. Non-destructive detection of water stress and estimation of relative water content in maize. Geophys. Res. Lett. 2009, 36, 1-4. [CrossRef]

47. Gamon, J.A.; Penuelas, J.; Field, C.B. A narrow-waveband spectral index that tracks diurnal changes in photosynthetic efficiency. Remote Sens. Environ. 1992, 41, 35-44. [CrossRef]

(C) 2019 by the authors. Licensee MDPI, Basel, Switzerland. This article is an open access article distributed under the terms and conditions of the Creative Commons Attribution (CC BY) license (http:// creativecommons.org/licenses/by/4.0/). 